\title{
FACTORS AFFECTING REPRODUCTIVE EFFICIENCY OF THE BREEDING HERD
}

\section{G.J. TOMES}

Muresk Agricultural College, Western Australia

and

\section{H.E. NIELSEN}

National Institute of Animal Science, Copenhagen, Denmark

The great variation that exists in the productivity of sow herds is well illustrated by a Danish survey based on a large number of commercial breeding herds where the number of piglets weaned/sow/year ranged from 10 to 22 (Aagaard and Studstrup, 1977). The financial consequences are clearly demonstrated in Figure 25.1 where overall profitability of the breeding unit rises as the number of pigs weaned/sow/year increases. It is impossible to make a general assessment of financial implications of reproductive efficiency for various countries but such a trend is general.

In herds producing small numbers of pigs/sow/year there are often many unproductive sows with the attendant penalties of extra feed, labour and

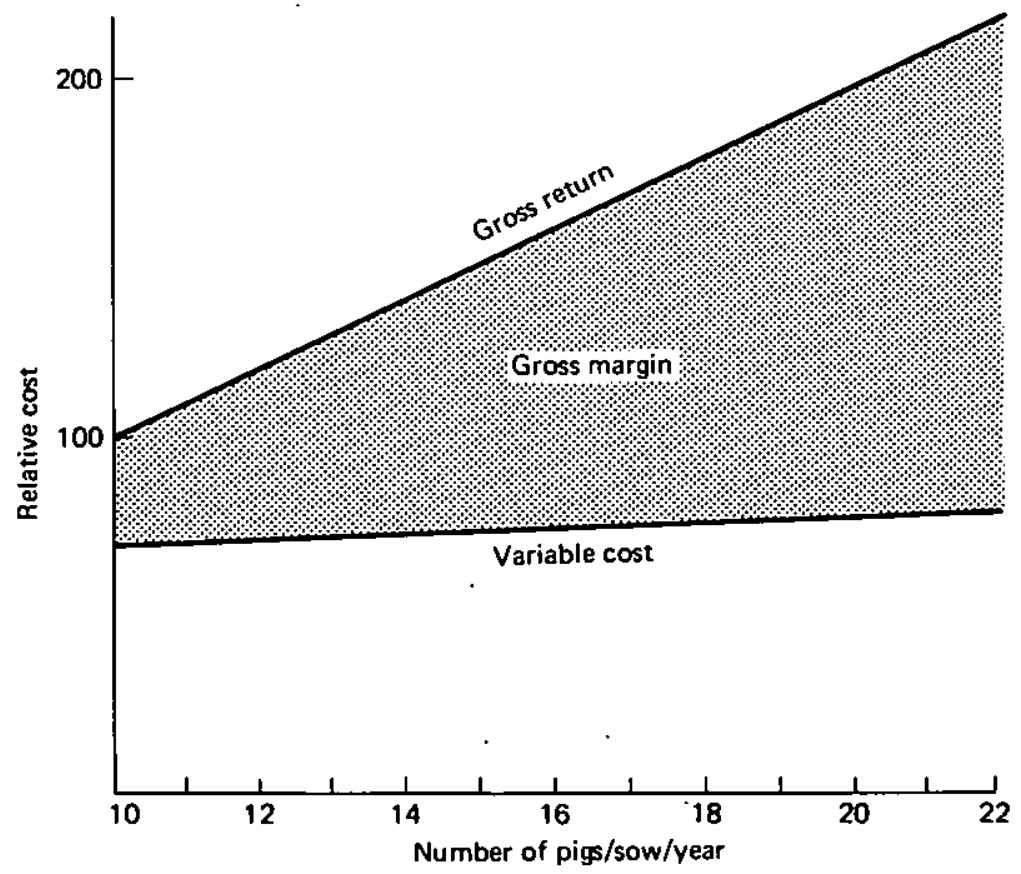

Figure 25.1 Profitability in breeding herds. From Aagaard and Studstrup (1977) 
Table 25.1 NUMBER OF SOWS NEEDED TO PRODUCE 1000 PIGS PER YEAR AT VARIOUS PRODUCTION LEVELS

\begin{tabular}{ll}
\hline No. of weaned pigs/sow/year & No. of sows needed \\
\hline 12 & 83 \\
16 & 62 \\
20 & 50 \\
24 & 42 \\
\hline
\end{tabular}

Table 25.2 UNPRODUCTIVE DAYS OF SOWS AT DIFFERENT LEVELS OF EFFICIENCY BASED ON A 5-WEEK WEANING SYSTEM

\begin{tabular}{|c|c|c|c|}
\hline $\begin{array}{l}\text { No. of litters/ } \\
\text { sow/year }\end{array}$ & $\begin{array}{l}\text { Sow empty } \\
\text { days }\end{array}$ & $\begin{array}{l}\text { Percentage of } \\
\text { the year } \\
(\%)\end{array}$ & $\begin{array}{l}\text { Equivalent herd sizes to achieve } \\
\text { same total margin over feed costs } \\
\text { (f) }\end{array}$ \\
\hline $\begin{array}{l}1.6 \\
2.2\end{array}$ & $\begin{array}{r}127 \\
37\end{array}$ & $\begin{array}{l}35 \\
10\end{array}$ & $\begin{array}{l}76 \\
50\end{array}$ \\
\hline
\end{tabular}

From Aherne (1980, personal communication)

under-utilized production facilities. Some production parameters for herds at different levels of efficiency are given in Tables 25.1 and 25.2. Pig producers are well aware that large litters and short intervals between farrowings are essential to maintain high annual output per sow (Nielsen 1981a). However, they often overlook the impact of herd age structure and culling patterns on reproductive efficiency. The major factors affecting reproductive efficiency in sow herds are given in Figure 25.2 and are discussed in this chapter.

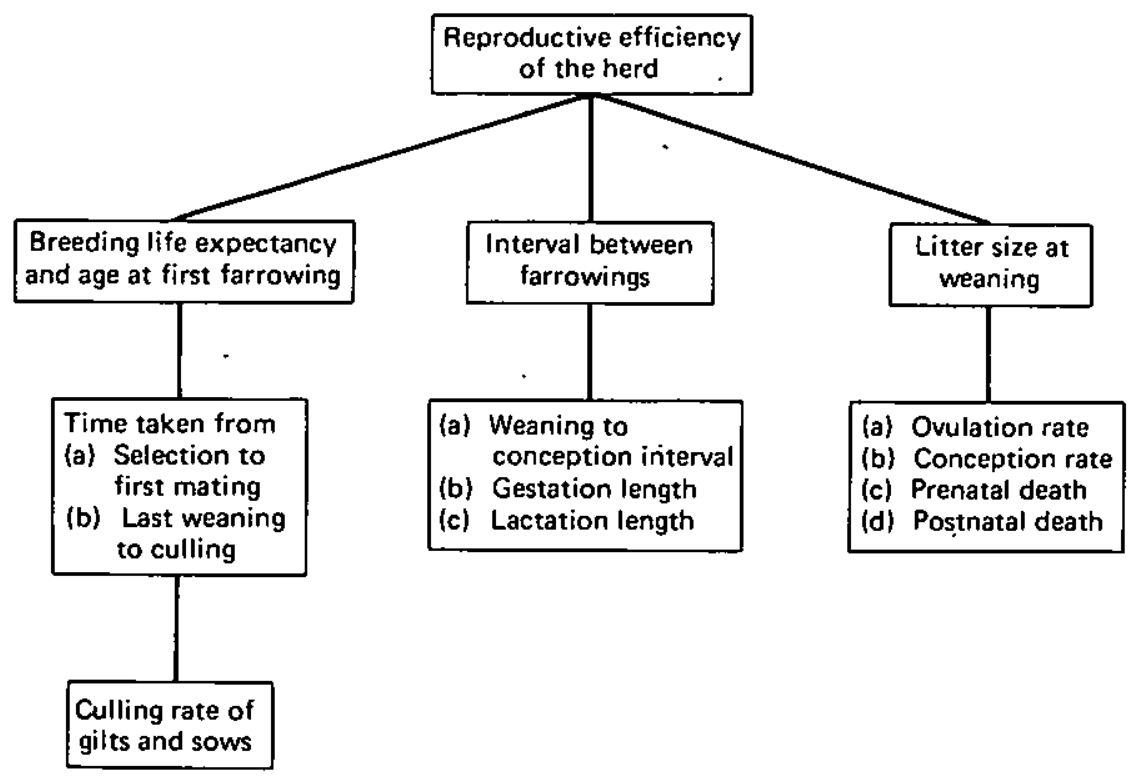

Figure 25.2 'The major factors affecting reproductive efficiency of the breeding herd 


\section{Breeding life expectancy and age at first farrowing}

\section{BREEDING LIFE EXPECTANCY}

The definition of 'breeding sows' varies in the literature and this causes problems when results of various studies are interpreted. An acceptable definition has been offered recently by Sundgren et al. (1980) who included all female pigs selected for breeding and older than 200 days.

Under commercial conditions there is a high wastage rate in sows, the main causes of culling being reproductive failure, leg problems and small litters (Tomes, Nielsen and Jacobsen, 1977). Reproductive failure may be connected with genotype, nutrition, housing conditions, herd health and management practices. A number of studies have shown that approximately $40 \%$ of sows are culled or die each year in European and Australian production units (Jones, 1967; 1968; Einarsson and Settergren, 1974; English, Smith and MacLean, 1977; Dagorn and Aumaitre,.1979; Tomes and Nielsen, 1979).

Culling rate has a great impact on the composition of sow herds and their productivity. Kroes and van Male (1979) have shown that herds with a low culling rate $(31.3 \%)$ produced on average 1.5 weaners/sow/year more than herds where $55.4 \%$ sows were replaced. The difference in profitability between units with low and high culling rates was even more pronounced. The average age of culled sows was low (24-35 months) and 35-45\% produced less than three litters.

Seasonal variations in the percentage of culled sows have been reported in Europe by Tomes, Nielsen and Jacobsen (1977) and by Dagorn and Aumaitre (1979). The large increase in the number of sows culled during summer and early autumn is caused by breeding failure. It may be due to heat, but is probably caused by other factors, as the temperatures seldom are critical in most parts of Europe. Results recorded in Australia (Tomes and Nielsen, 1979) show culling rates similar to those found in Europe, but the proportion of animals dying reached $8 \%$ (cf. approximately $3 \%$, of the sow population recorded in Denmark). Most of these losses occurred during hot summers when the temperature in the piggery was in the vicinity of $40^{\circ} \mathrm{C}$. Sows at late pregnancy or shortly after farrowing are particularly susceptible to high temperatures. Speer (1981) has confirmed increased sow mortality during hot summer months; for sows kept under nonconfinement he also observed marked increases in mortality during harsh winters.

Reports in the literature suggest that only about $30 \%$ of sows produce more than five litters, i.e. reach the period when the largest litters can be expected (Dagorn and Aumaitre, 1979). However, in many herds sows can produce six or more litters before culling (Dagorn and Aumaitre, 1979).

Individual attention, efficient oestrous detection and the close supervision of mating are the prerequisites for long breeding life and increased productivity in sow herds. Under most conditions the standard of management and stockmanship is the most important factor determining the breeding life expectancy. Several devices exist for detecting pregnancy in pigs; however, Aumaitre and Etienne (1981) have claimed that a boar detecting heat gives as good a result as any of the equipment available. 
It is essential that non-productive animals are identified and excluded from the herd as soon as possible. Failure to do so has a substantial effect on herd output. Long delays in culling sows from commercial herds were reported by Pomeroy (1960), Dagorn and Aumaitre (1979) and Pattison, Cook and Mackenzie (1980a,b). Kroes and van Male (1979) calculated that the time lost as a result of culling increased the average farrowing interval by six to eight days. Efficient culling must be accompanied by a ready supply of replacement gilts to avoid a suboptimal sow population and the corresponding economic penalties.

\section{AGE AT FIRST FARROWING}

The selection and pre-service management of gilts is an area of major change and development. Not so long ago a pig often took over 200 days to reach $90 \mathrm{~kg}$ liveweight and gilts were first mated between 8-10 months of age (third oestrus). This practice was based on studies showing that gilts served at third oestrus produced larger litters than those served at first oestrus (Pay and Davies, 1973).

Under good production conditions gilts can reach $90 \mathrm{~kg}$ in less than 150 days (Barker, 1979). Many such animals are capable of reaching puberty when exposed to mature boars at this stage (Brooks and Cole, 1970). Examples of the early onset of puberty in gilts are presented in Figures 25.3 and 25.4. There is also substantial evidence that gilts served at second or third oestrus by the time they reach market weight will produce as large a litter as those served at $130 \mathrm{~kg}$ or 8 months (Brooks and Cole, 1973; Pay and Davies, 1973). The subsequent production life of these early mated animals appears to be similar to those mated later (Brooks and Smith,

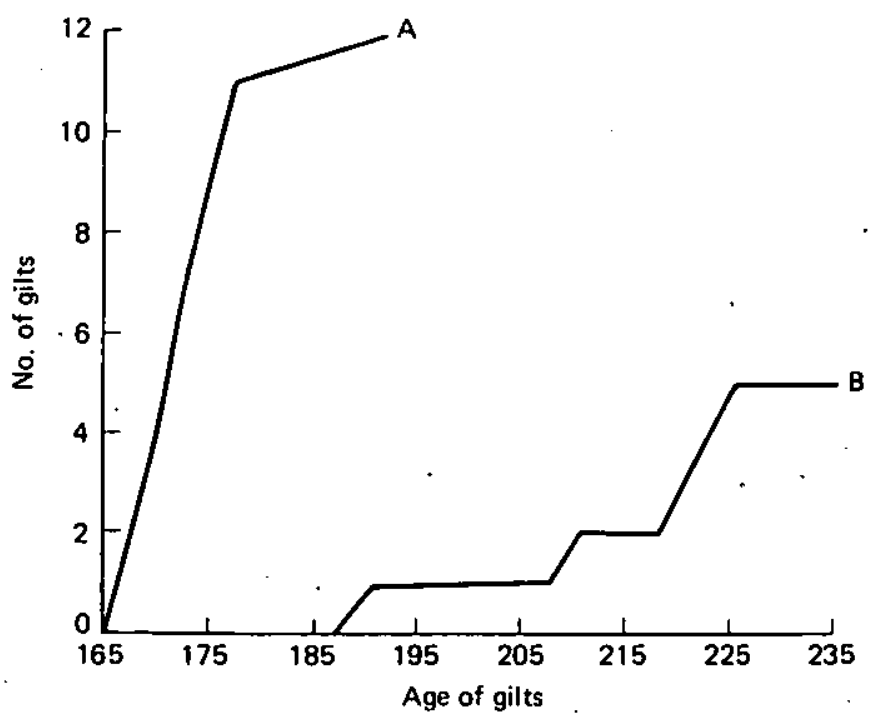

Figure 25.3 The effect of boar presence or absence on attainment of puberty in gilts. A: boars introduced at 165 days; B: no boars present. From Brooks and Cole (1970) 


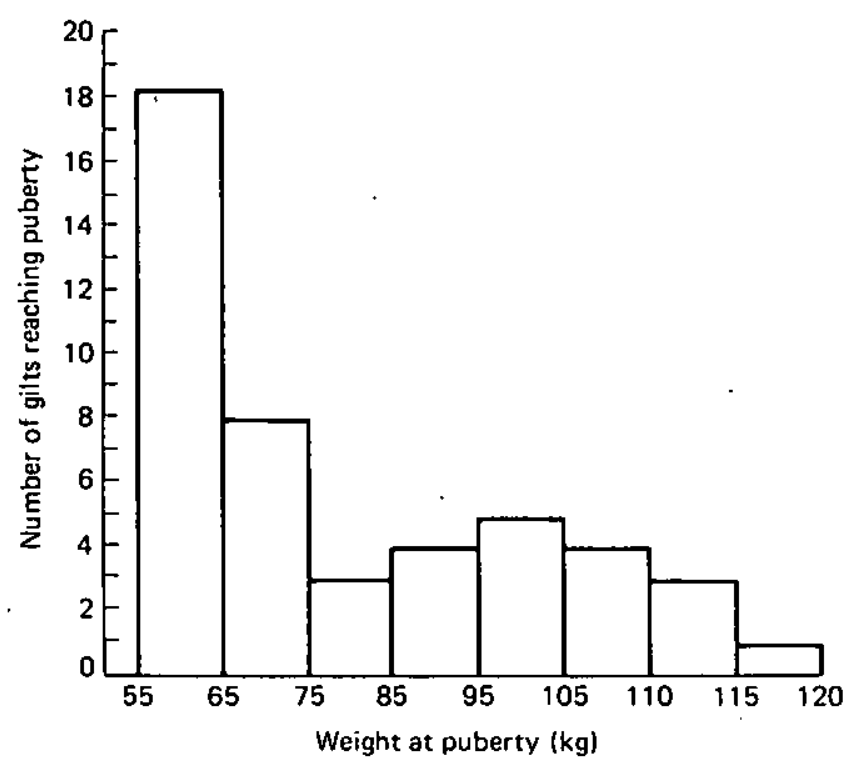

Figure 25.4 The distribution of weight at puberty in Lacombe gilts following exposure to boars. From Aherne et al. (1976)

1980). Often conflicting opinions exist about the optimum age for mating and about replacing gilts in commercial herds. O'Grady (1979) has recommended not to mate before the gilts reach 240 days of age; Brooks and Smith (1980) have advocated mating at second heat but as early in life as possible.

Gilts produce smaller litters than older sows and the individual birthweights of first litter pigs are also lower than of those from older sows (Nielsen, 1968). There is some evidence to suggest that piglets born in first litters are more susceptible to infection than piglets from older sows. However, when the gilts are properly introduced into the herd, protection via colostrum and milk is adequate (Kruse, 1981).

A practical system benefiting producers in terms of reduced food consumption and earlier production from gilts has been described by Aherne (1979, unpublished data) and is shown in Figure 25.5. Gilts are housed separately after weaning until they reach a weight of approximately $65 \mathrm{~kg}$. Mature boars are then introduced for a period of 10 days and all gilts showing. strong and consistent heats within three weeks are considered for breeding. At third heat the selected animals are served. The number of gilts served should be.considerably higher than the required number of breeding animals to allow for the final selection among served gilts. Gilts returning to oestrus, some pregnant animals above the requirement for replacements and those rejected for various other reasons are marketed.

This method is likely to increase the consistency of heats by selection. It also provides a ready pool of replacements essential to avoid seasonal changes caused by delayed puberty (Bane, Einarsson and Larsson, 1976; Tomes and Nielsen, 1979) or increased culling rate (Tomes, Nielsen and Jacobsen, 1977; Dagorn and Aumaitre, 1979). Nielsen (1981b) reported 


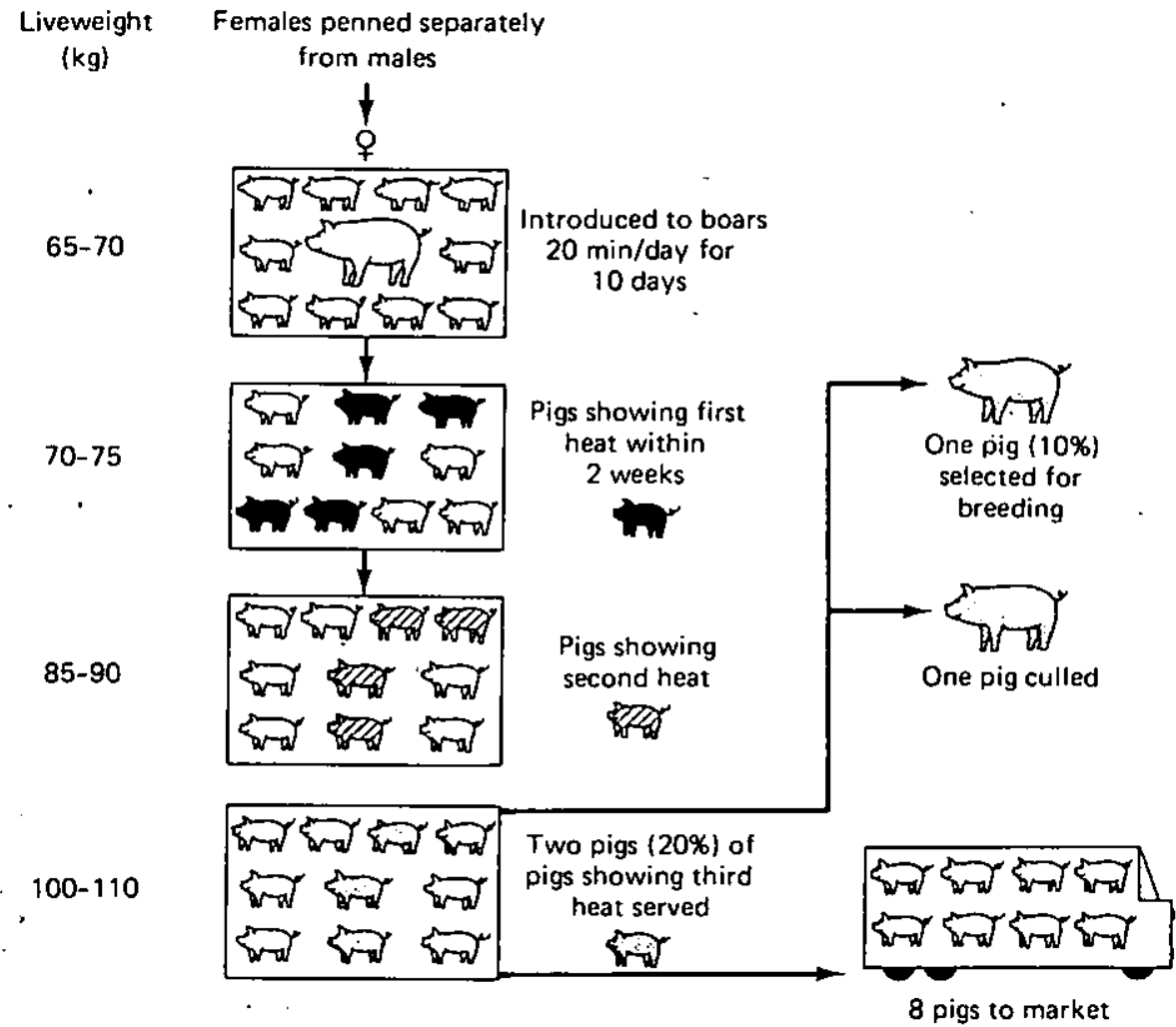

Figure 25.5 Selection of female pigs for breeding

the use of Aherne's method in a large Danish unit and recommended it for application in batch farrowing systems as suggested by Nielsen and Danielsen (1976).

\section{Interval between farrowings}

The number of piglets produced/sow/year can be increased by reducing the interval between farrowings. This can be done by reducing lactation length and the period between weaning and conception.

Normal gestation can range from 112-118 days and although a negative correlation exists between gestation period and the number of pigs born, little can be done under commercial conditions to shorten gestation. Prostaglandin analogues are increasingly used to induce parturition in commercial herds. Average gestation length is reduced by 1-3 days but there may be even greater potential benefits resulting from reduced perinatal losses and more efficient use of farm labour (King, 1981).

In theory the number of litters/sow/year may be increased by approximately 0.1 if lactation is shortened by one week (Figure 25.6). Practical results show a smaller improvement, particularly when very short lactation periods are adopted. 


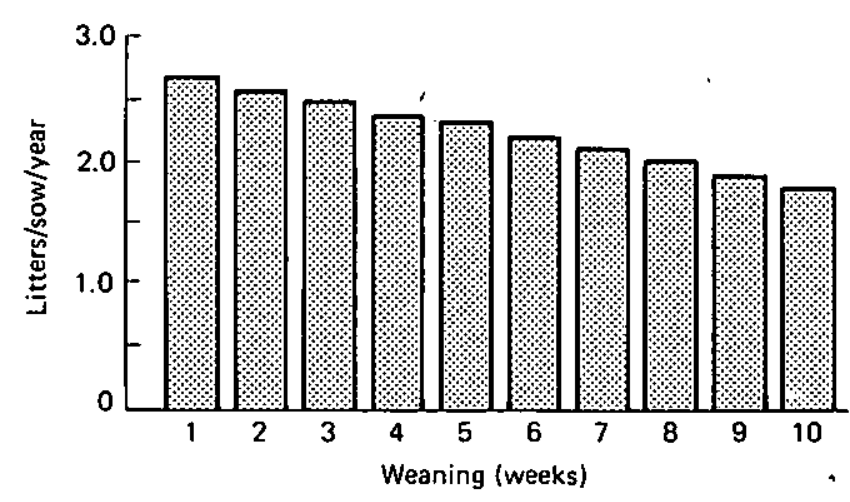

Figure 25.6 Theoretical number of litters/sow/year with various lactation lengths

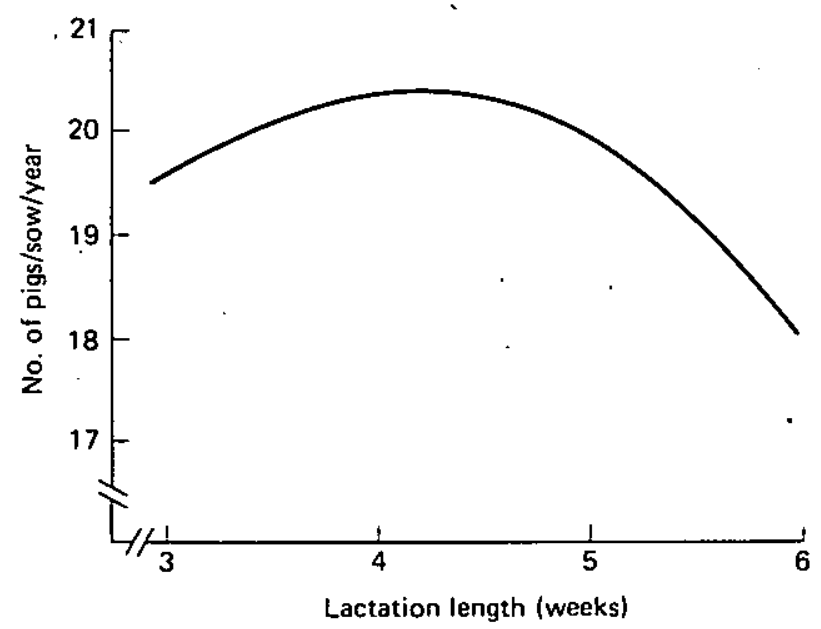

Figure 25.7 The influence of lactation length on the number of pigs/sow/year. From Danielsen and Ruby (1979)

In a recent comprehensive study, Danielsen $(1980 \mathrm{~b})$ has stated that weaning before four weeks is detrimental to overall productivity. Weanings before three weeks of age may result in more litters/sow/year but will also cause a significant reduction in subsequent litter size (Varley and Cole, 1976; te Brake, 1978). Other reproductive parameters such as the incidence of post-weaning oestrus (Allrich et al., 1979; Danielsen, 1980a) and conception rate (Varley and Cole, 1976) are also negatively affected by shorter lactation length. Figure 25.7 shows the effect of lactation length on the annual production of piglets/sow recorded in a comprehensive Danish study. Results recorded in the literature generally suggest lactation lengths of 21-30 days for maximum production/sow/year. The characteristics of individual herds are likely to be important in determining where within this interval highest productivity can be achieved.

The period between weaning and conception varies considerably between herds. Results recorded in research studies indicate that the normal period between weaning and oestrus is $4-7$ days. In commercial units, 
Table 25.3 PATTERN OF RETURN TO SERVICE ON FRENCH FARMS

\begin{tabular}{lc}
\hline Days after weaning & $\begin{array}{l}\text { Sows mated } \\
(\%)\end{array}$ \\
\hline $1-14$ & 58.5 \\
$15-20$ & 5.5 \\
$21-30$ & 9.5 \\
$31-40$ & 8.5 \\
$41-50$ & 6.8 \\
Over 50 & 11.2 \\
\hline
\end{tabular}

From Legault, Dagorn and Taster (1975)

Table 25.4 EFFECT OF PARITY ON THE INTERVAL FROM WEANING TO MATING EXPRESSED AS A PERCENTAGE OF SOWS RETURNING IN THE TIME SPECIFIED

\begin{tabular}{lllll}
\hline Parity & \multicolumn{4}{c}{ Days after weaning } \\
\cline { 2 - 5 } & $0-10$ & $11-23$ & $24-30$ & 30 \\
& $(\%)$ & $(\%)$ & $(\%)$ & $(\%)$ \\
\hline $1(n=2143)$ & 70.6 & 14.8 & 8.1 & 6.5 \\
$2-9(n=5939)$ & 92.4 & 4.8 & 1.9 & 0.9 \\
\hline
\end{tabular}

From Paterson, Barker and Lindsay (1980)

under excellent conditions, this period may be shorter than 10 days (Paterson, Barker and Lindsay, 1980) but it is generally far longer (Dagorn and Aumaitre, 1979). Table 25.3 shows results from a French survey (Legault, Dagorn and Taster, 1975) where less than $60 \%$ of sows were served within two weeks after weaning. The onset of oestrus is delayed in primiparous sows, and Paterson, Barker and Lindsay (1980) have reported that primiparous sows are mated on average five days later after weaning than older sows. Some of their results are presented in Table 25.4. They also found that crossbred sows exhibited oestrus on average two days earlier than purebred Landrace sows and nearly one day before purebred Large White sows.

Tomes and Nielsen (1979) compared reproductive performance in Australia and Denmark and found that seasonal anoestrus and low conception rates occurred in both countries despite the great difference in seasonal temperature.

Delayed oestrus is usually associated with low conception rates (Einarsson, 1977; Miskovic, Cerne and Jancic, 1977) and with shorter periods of standing heat (Tomes and Smith, 1975). Several factors may be responșible for the lack of normal oestrus in sows. The presence of mature boars has a marked stimulating effect on breeding activity in sows (Hughes and Cole, 1976). Newly weaned sows and gilts approaching maturity should be housed in close proximity to mature boars (English, Smith and MacLean, 1977). Increased intake of feed during lactation and prior to oestrus may stimulate early post-weaning oestrus in primiparous sows (Tomes, 1978a). The level of feeding of young sows is important; Whittemore, Franklin and Pearce (1980) have shown that the amount of body fat is reduced considerably during the first two parities even when the sows are fed up to $2 \mathrm{~kg}$ feed/day. 


\section{Litter size}

The main factors determining litter size at weaning are shown in Figure 25.2. The first limit imposed on the potential litter size is ovulation rate. The number of ova is higher for sows than for gilts, but in gilts there is a pronounced increase in ovulation after the first oestrus. MacPherson, Hovell and Jones (1977) noted that gilts mated at first, second and third oestrus produced $7.8,9.8$ and 10.2 piglets, respectively, when they first farrowed.

When gilts are fed a low plane of nutrition, an increased energy intake for 10-14 days before mating usually results in increased ovulation rate (Zimmerman, Spies and Self, 1960) but its effect on live litter size is inconsistent (Brooks and Cole, 1973). Larger litters are usually recorded only with young, lean sows. Tomes (1978a) found no response to increased energy intake after second parity. There is also evidence suggesting that the administration of antibiotics at parturition may increase ovulation rate (Hays et al. , 1978). Some producers practise starvation of the sows after weaning. Shearer and Adam (1973) have shown that starvation can have an adverse effect on the onset of oestrus and on conception rates. It is recommended that high levels of feeding are used during the first week after weaning.

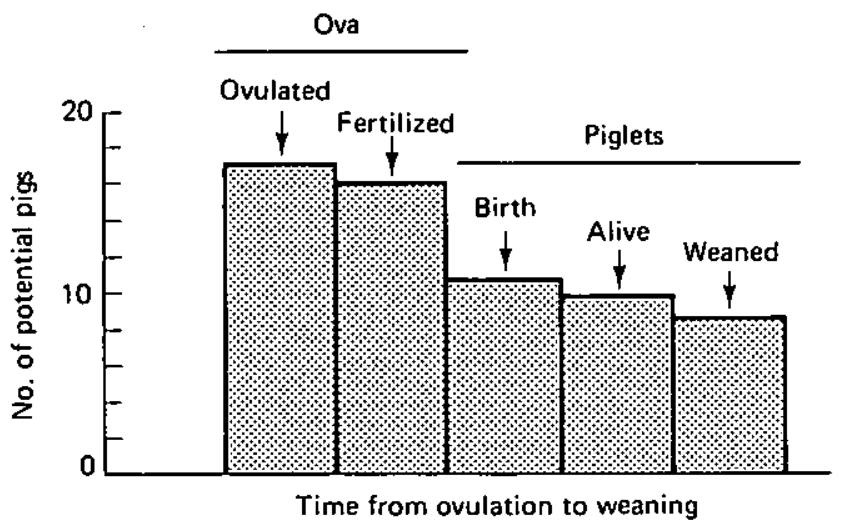

Figure 25.8 Loss of potential pigs from the time of ovulation until weaning. From Schofield (1972)

Under normal conditions nearly all eggs are fertilized after mating (Figure 25.8). However, the chances of conception are reduced if the sow or gilt is mated too early or too late during oestrus. The timing of mating also affects litter size. This phenomenon has been studied by Polge (1974) and his results are presented in Figure 25.9. It should be noted, however, that ovulation does not occur at a specific time after the onset of oestrus (boar acceptance). This may explain the usual increase in conception rate and even in litter size when sows and gilts are mated twice or three times.

Changes in ovulation patterns caused by the administration of high levels of exogenous gonadotrophins may be used to explain reduced conception rates after superovulation (Tomes, 1978b). Relatively low levels of exogenous gonadotrophins have not been found to depress conception and are 


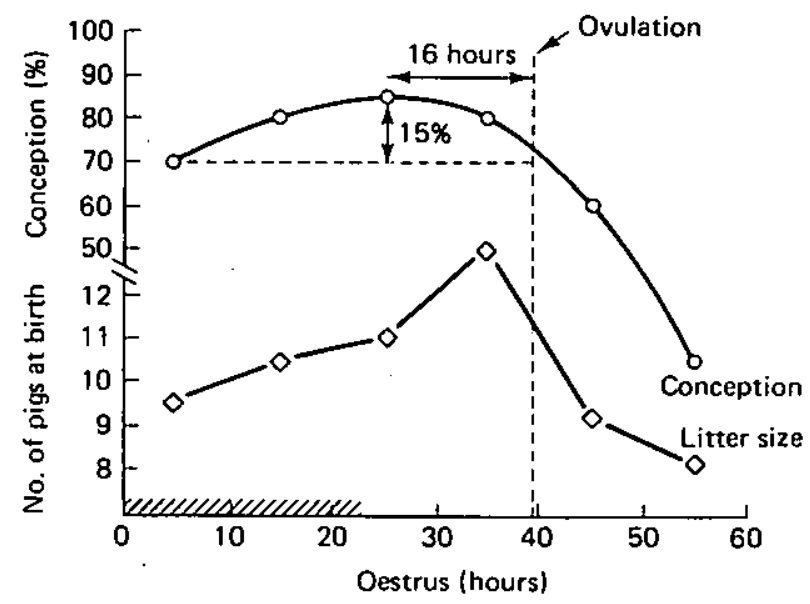

Figure 25.9 Conception and litter size in relation to time of mating. From Polge (personal communication)

commonly used to stimulate and synchronize oestrus in herds with a previous history of reproductive disturbances.

Conception rate and infertility depend on environmental conditions e.g. climate (Table 25.5) and on the health of the sows and fertility of the boars. Several workers have reported big differences in conception rate and litter size when individual boars have been evaluated (Skjervold, 1963; Nielsen, 1968; Garnett, 1981). These differences often exceed $23 \%$ in conception rate and two piglets/litter. Significant improvements in production can be made if young boars are tested with a relatively small number of sows $(30-40)$ and then only considered for further breeding. This is particularly relevant in large units and with artificial insemination.

Table 25.5 SUMMER INFERTILITY IN SOWS IN AUSTRALIA

\begin{tabular}{llll}
\hline $\begin{array}{l}\text { Temperature range } \\
\left({ }^{\circ} \mathrm{C}\right)\end{array}$ & $\begin{array}{l}\text { Duration } \\
\text { (weeks/year) }\end{array}$ & Total no. of services & $\begin{array}{l}\text { Returns } \\
(\%)\end{array}$ \\
\hline $20-23.9$ & 7.8 & 1116 & 12.2 \\
$24-27.9$ & 15.1 & 2584 & 11.4 \\
$28-31.9$ & 13.1 & 2392 & 14.4 \\
$\leqslant 32$ & 16.0 & 2919 & 19.7 \\
\hline
\end{tabular}

From Paterson (1978)

The role of crossbreeding as an effective method of increasing the number of pigs produced/sow/year is well recognized by pig breeders and is further discussed, in addition to other genetic means of improving productivity, in Chapter 26.

Prenatal and postnatal mortality cause serious problems in many herds. The economical implications are often underestimated by producers. This wide ranging area is beyond the scope of this chapter and detailed information can be found in Chapters 12, 13 and 23.

More emphasis should be placed on monitoring the performance of individual boars where large savings can be achieved by early culling of 
those with low libido, poor conception rate or small litters. In addition, recent results (Tomes and Nielsen, 1979) show seasonal variation in the birthweights of piglets and also differences resulting from the use of various sires (Tomes, unpublished).

There is a clear need for more information about individual boars, and about the subsequent performance and survival of piglets sired by them. In the meantime a significant improvement in litter size may be achieved by double mating using two different boars during the same oestrus instead of the usual two matings with one boar (Meding, 1979 unpublished). Although this system is suitable only for the production of slaughter pigs it can increase the annual production per sow by $0.6-0.8$ at no extra cost.

\section{References}

AAGAARD, R. and STUDSTRUP, N. (1977). Svineholds okonomi. Landsudvalget for driftsøkonomi. Det Fagligte landscenter, Viby, Denmark

AHERNE, F.X., CHRISTOPHERSON, R.J. THOMPSON, J.R. and HARDIN, R.T. (1976). Factors affecting the onset of puberty, post-weaning estrus and blood hormone levels of Lacombe gilts. Can. J. Anim. Sci. 56, 681-692

ALLRICH, R.D., TILTON, J.E., JOHNSON, J.N., SLANGER, W.D. and MARCHELLO, M.J. (1979). Effect of lactation length and fasting on various reproductive phenomena of sows. J. Anim. Sci. 48, 359-362

AUmAITre, A. and ETIENNE, M. (1981). Proceedings Guelph Pork Symposium. Management of the Sow and Young Pig. University of Guelph, pp. $1-16$

BANE, A., EINARSSON, S. and LARSSON, K. (1976). Effect of season on age at puberty in crossbred gilts in Sweden. VIIth Int. Congr. Anim. Reprod., Krakow, pp. 117-119

BARKer, I. (1979). Australian Pig Manual, p. 191. Australian Pig Industry Research Committee

TE BRAKE, J.H.A. (1978). An assessment of the most profitable length of lactation on producing piglets of $20 \mathrm{~kg}$ body weight. Livest. Prod. Sci. 5, $81-94$

BROOKS, P.H. and COLE, D.J.A. (1970). The effect of presence of a boar on the attainment of puberty in gilts. J. Reprod. Fert. 23, 435-440

BROOKS, P.H. and COLE, D.J.A. (1973). Meat production from pigs which have farrowed. 1. Reproductive performance and food conversion efficiency. Anim. Prod. 17, 305-315

BROOKS, P.H. and SMITH, D.A. (1980). The effect of mating age on the reproductive performance, food utilization and liveweight change of the female pig. Livest. Prod. Sci. 7, 67-78

DAGORN, J. and AUMAITRE, A. (1979). Sow culling: reason for and effect on productivity. Livest. Prod. Sci. 6, 167-178

DANIELSEN, V. (1980a). Results favour 4-week weaning. Pig International $10,6.50$

DANIELSEN, V. (1980b). The effect of weaning age on reproductive performance in the pig. E.A.A.P. Commission on Pig Production, Munich

DANIELSEN, V. and RUBY, V. (1979). Evaluation of data from experiments 


\section{Factors affecting reproductive efficiency of the breeding herd}

and field test on reproductive performance in sows. E.A.A.P. Commission on Pig Production, Harrogate

EINARSSON, S. (1977). Disturbances in reproduction and measures for reduction of these phenomena. E.A.A.P. Commission on Pig Production, Brussels

EINARSSON, S. and SETTERGREN, I. (1974). Fertility and culling in some pig breeding herds in Sweden. Nord. VetMed. 26, 576-584

ENGLISH, P., SMITH, W. and MACLEAN, A. (1977). The sow - improving her efficiency. Farming Press, Suffolk. p. 305

GARNETT, I. (1981). Important Factors to be considered in selecting your Breeding Sow. Proceedings of Alberta Pork Seminar, University of Alberta, pp. 160-167

HAYS, V.W., KRUG, J., CROMWELL, L., DUTT, G.L. and KRATZER, D.D. (1978). Effect of lactation length and dietary antibiotics on reproductive performance of sows. J. Anim. Sci. 46, 884-891

HUGHES, P.E. and COLE, D.J.A. (1976). Reproduction in the gilt. 2. The influence of gilt age at boar introduction on the attainment of puberty. Anim. Prod. 23, 89-94

JONES, J.E.T. (1967). An investigation of the causes of mortality and morbidity in sows in a commercial herd. Br. vet. J. 123, 327-339

JONES, J.E.T. (1968). The cause of death in sows. A one year survey of 106 herds in Essex. Br. vet. J. 124, 45-55

KING, G.J. (1981). Proceedings Guelph Pork Symposium. Management of the Sow and Young Pig. University of Guelph, pp. 43-47

KROES, Y. and VAN MALE, J.P. (1979). Reproductive lifetime of sows in relation to economy of production. Livest. Prod. Sci. 6, 179-183

KRUSE, P.E. (1981). Immunity - what you should know. Proceedings Alberta Pork Seminar, University of Alberta, pp. 49-65

LEGAULT, C., DAGORN, J. and TASTER, D. (1975). Journées de la recherche porcine en France, pp. 43-51. Paris, L'Institut Technique du Porc

MACPHERSON, R.M., HOVELL, F.D. and JONES, A.S. (1977). Performance of sows first mated at puberty or second or third oestrus, and carcass assessment of once-bred gilts. Anim. Prod. 24, 333-343

MISKOVIC, M., CERNE, F. and JANCIC, S. (1977). Losses in gilts and sows and their principal causes in large units. E.A.A.P. Commission on Pig Production, Brussels

NIELSEN, H.E. (1968). Growth rate, fertility and longevity of boars on different gilts during rearing, and some results concerning fertility in sows. Report from National Institute of Animal Science, Copenhagen, p. 375

NIELSEN, H.E. (1981a). Sow productivity. Proceedings Alberta Pork Seminar, University of Alberta, pp. 1-17

NIELSEN, H.E. (1981b). Gilt selection and management to farrowing. Proceedings Guelph Pork Symposium. Management of the Sow and Young Pig. University of Guelph, pp. 1-16

NIELSEN, H.E. and DANIELSEN, V. (1976). Maximising reproduction in pigs. Proc. Pig Vet. Soc. 1, 76-89

O'GRADY, J.R. (1979). Proceedings Pork Industry Conference, University of Illinois, pp. 59-66

paterson, A.M. (1978). J. exp. Agric. Anim. Husb. 18, 691-698

PATERSON, A.M., BARKER, I. and LINDSAY, D.R. (1980). Proc. aust. Soc. Anim. Prod. 13, 389-392 
PATTISON, H.D., COOK, G.L. and MACKENZIE, S. (1980a). A study of natural service farrowing rates and associated fertility parameters. Anim. Prod. 30, 452 (Abstract)

PATTISON, H.D., COOK, G.L. and MACKENZIE, S. (1980b). A study of culling patterns in commercial pig breeding herds. Anim. Prod. 30, 462-463 (Abstract)

PAY, M.G. and DAVIES, T.E. (1973). Growth, food consumption and litter production of female pigs mated at puberty and at low body weight. Anim. Prod. 17, 85-91

POLGE, C. (1974). Meeting of the European Association of Animal Production, Copenhagen, 1974, Unpublished data

POMEROY, R.W. (1960). Infertility and neonatal mortality in the sow. $J$. agric. Sci., Camb. 54, 18-31

SCHOFIELD, A.M. (1972). Embryonic mortality. In Pig Production, (D.J.A. Cole, Ed.), pp. 367-383. London, Butterworths

SHEARER, I.J. and ADAM, J.L. (1973). Nutritional and physiological development in reproduction of pigs. Proc. N.Z. Soc. Anim. Prod. 33, 62-76

SKJERVOLD, H. (1963). To what extent do boars affect the litter size? The Agricultural University of Norway, Report 166

SPEER, V.C. (1981). Feeding sows during lactation. Proceedings Guelph Pork Symposium. Management of the Sow and Young Pig. University of Guelph, pp. 19-29

SUNDGREN, P.E., VAN MALE, J.P., AUMAITRE, A., KALM, E. and NIELSEN, H.E. (1980). Sow and litter recording procedures. Report of a working party of the EAAP Commission of Pig Production. Livest. Prod. Sci. 7, 393-401

TOMES, G.J. (1978a). Effects of post-weaning feeding levels and pregnant mares serum gonadotrophin (PMSG) on sow reproductive performance. Proc. aust. Soc. Anim. Prod. 12, 255

TOMES, G.J. (1978b). Influence of short term feed intake variation and hormonal supplements on sow reproductive performance. PhD Thesis. University of Western Australia

TOMES, G.J. and NIELSEN, H.E. (1979). Seasonal variation in the reproductive performance of sows under different climatic conditions. Wld Rev. Anim. Prod. XV 1, 9-20

TOMES, G.J. and SMITH, C.A. (1975). Effect of energy intake and hormonal supplements on litter size. Proc. Aust. Pig Prod. Rev. Conf. 2, 101-103

TOMES, C.J., NIELSEN, H.E. and JACOBSEN, K.A. (1977). Review of 15 years recording of culling sows in Danish production units. E.A.A.P. Commission on Pig Production, Brussels

VARLEY, M.A. and COLE, D.J.A. (1976). Studies in sow reproduction. 5. The effect of lactation length of the sow on subsequent embryonic development. Anim. Prod. 22, 79-85

WHITTEMORE, C.T., FRANKLIN, M.F. and PEARCE, B.S. (1980). Fat change in breeding sows. Anim. Prod. 31, 181-190

ZIMMERMAN, D.R., SPIES, H.G. and SELF, H.J. (1960). Ovulation rate in swine as affected by increased energy intake just prior to ovulation. J. Anim. Sci. 19, 295-301 